\title{
Organizations need Ethical Leaders: How to Attract and Nurture Cultural Creatives Into Positions of Leadership and Influence
}

\begin{abstract}
Purpose

This paper looks at the growing need for ethical leaders, suggesting that a strata of society called "Cultural Creatives" may answer that need. It investigates how the Cultural Creatives can be attracted to and nurtured in positions of leadership and puts forward tangible action points and suggestions to help organizations take practical actions. 53

\section{Design/Methodology}

The paper is an Interpretative Phenomenological analysis of four Cultural Creatives who are in positions of leadership. 17

Findings

Participants were predictably people oriented, although this meant different things for each person. Their styles of leadership varied, but all shared a desire to become a role model and leave a legacy.

Only one worked within the third sector and all were very pragmatic and motivated by money, something that seems to be different from the original research on this group.61

Research Limitations/Implications
\end{abstract}




\section{Practical Implications/Limitations}

The paper highlights five key indicators organizations must consider in order to attract and nurture Cultural Creatives : flexibility in leadership style; levels of autonomy; acting as mentors; appropriate financial rewards and opportunities for authentic, self determined work.

3880

Social Implications

The Cultural Creatives are reportedly the third largest social strata in Western society, after the Modernists and Traditionalists. They are growing as a group, and this study looks at how they operate and feel about their workplace. It provides insight into what is like to be a Cultural Creative.

Originality/Valve

This is the only known research on Cultural Creatives since the original research in the early 2000s. 17

\section{Introduction}

The phrase "ethical leadership" is becoming more prevalent, but what is it? (Brown et al, 2005) describe ethical leadership as "appropriate conduct through personal actions and interpersonal relationships," but Darcy (2010) suggests it is deeper than mere behaviour: a way of being with values at its core.

Certainly, there are clues we are turning to ethical leaders. In the UK, Social Enterprises outnumber SME start-ups 3:1 and the CMI suggests ethical leadership is key to long term economic growth. 
How can organizations find morally-driven leaders? Research points to three major social strata in western society today (Ray \& Anderson, 2000):

- Dominating - materialist and technologically savvy 'Moderns',

- a near second - family orientated, traditional gender role respecting 'Traditionalists',

- Lastly - ethical, values-driven 'Cultural Creatives'.

Cultural Creatives overlap with both categories, but the aforementioned research describes their separate values-driven identity as:

- Authenticity: They "invented the current interest in personal authenticity."

- Engaged Action: They like to be involved in "the whole Process, where they be can part of something from the beginning." They are prosocial, altruistic and "They expect to follow through on their values with personal action."

- Globalism and the Economy: They take a world view, instinctively knowing everything connects. They see things long-term, with ecology high on their list.

- Anti-materialist. They reject the constant need to own more "stuff", displays of status and are openly critical of big institutions and government.

Ray and Anderson estimated over 50 million US citizens are Cultural Creatives, with double that number in Europe. Cultural Creative values also appear to correspond with those of Millennials (born 1980-2000), such as concern around social and environmental issues.

\section{Why Ethical Leadership?}

There is a strong bottom line argument for ethical leadership. Low-carbon environmental goods and services are growing year on year (The UK reports 
$3.8 \%$ growth in 2012). This market may be driven by the pro-ecological Cultural Creatives, making them ideal candidates for leadership in this area.

CSR has become mandatory in many countries, with information on CSR activities increasingly demanded by stakeholders as well as the public. In this world of social media, public scrutiny cannot be avoided.

There may be strong instinctive reasons why we yearn for ethical leadership such as hunter-gatherer societies where power is given to those who live, hunt and fight with the greater good of the group in mind.

\section{The Research}

A deep-dive into the professional lives of four female leaders who fitted the definition of Cultural Creatives was undertaken. In an analysis of men and women in business and political elites, men were found to have a more directive and competitive style of leadership (Vianello \& Moore, 2004) which means a mixed-gender study may produce different results.

Participants were self-selecting, drawn from the researcher's extended network (which may also have some bearing on findings) and four chosen via an informal interview.

Semi-structured, hour-long interviews were undertaken and later transcribed. An Interpretive Phenomenological Analysis (IPA) approach was used to uncover the detailed perspectives of participants.

This article presents the resultant key themes, highlighting tangible implications for business.

\section{Leadership styles}

We often see "people orientated" on a job description. Each of our interviewees could be described as "people orientated", but there were significant differences.

For one, it inspired a servant leadership response, nurturing for a good working environment, for another it meant something transactional, paying 
well to instil loyalty. Yet another thought big picture: "People" are responsible for others and should step up, while, for one "People" are resources to manage, like budgets. All of them, however, were more interested in people than processes, and used their position to improve the working lives and relationships of others. Highlighting opportunities to nurture others like this may be an attraction.

\section{Power of Money}

Only one participant worked exclusively in the third sector and all were pragmatic about the power of money. One acknowledged she would have a much easier, and more financially lucrative time in private employment, whilst another referenced the private sector's lack of bureaucracy and red tape. Money is a driver, in some form, for all.

\section{Autonomy v support}

As leaders, they would be expected to have a high level of both efficacy and self-efficacy. When it came to Autonomy, there were more similarities than differences. Three participants suggested their Autonomy may have prevented them being offered support or training. Rather than ask for support, they moved on, starting their own consultancy or moving to another organization.

While they may have understood the reasons for the lack of support, acknowledging budgets or the pressures of a growing business, all ultimately, left. Organizations cannot assume people will ask for support or training. A proactive, even prescriptive approach, may help. Likewise, organizations would benefit from investigating what support means to individuals.

\section{Role models and mentors}

Despite being probed about their own role models, all participants brought up the subject of themselves as a role model without prompting. Their moral and pro-social behaviour may be prompted by reciprocal altruism, where 
they expect, even unconsciously, to gain a benefit in long-term reputation as a result, but it appeared to be a strong driver for every participant.

Mentorship (or sponsorship) may well prove an outlet for that need. Positive action to establish a system where Cultural Creatives mentor other Cultural Creatives could be a beneficial experience for all, creating a supportive community.

\section{Authenticity}

" Authenticity" was a strong theme. One interviewee said of her work, "it gives me an opportunity to really be me." Authenticity has been shown to play a significant part in higher states of well-being and psychological functioning, which may have contributed towards their climb to leadership. However, it is highly possible that a position which changes and does not feel authentic anymore may prompt dissatisfaction and ultimately result in the leader moving onto something more fulfilling. It is suggested that individuals should participate in their own job design to bring to life what it means to be "Authentic" for them.

\section{Types of work and challenges}

Although their work was pro-social, it was often in complex areas that come under the banner of Wicked Problems (Rittel 1969). Wicked Problems are probably unsolvable; certainly complicated with ever moving goalposts. They are often compared to a chess game. The participants' work within global warming and the environment, mental health, poverty and human trafficking bring them into this category. One, with a global lens, has even been drawn to a Super-Wicked problem, which has the added pressure of time running out.

All four use persuasion. One concentrated on building personal connections to increase networks, another persuaded firms to buy into CSR with financial arguments. Another's work necessitates her wielding compelling influence 
that can change people's lives, whilst our final interviewee uses client stories to influence policy around mental health.

\section{Conclusion}

The above all suggests that Cultural Creatives are a good fit for work that involves Wicked Problems, influence and persuasion...maybe because they have the moral passion to drive them to fight for change? The implications for those organizations wishing to embrace and drive change are good, perhaps less so for those content with a behemoth status.

Organizations can attract and nurture Cultural Creatives by:

- Highlighting opportunities to help others

- Recognising that money will be a significant motivator

- Giving them opportunities to inspire and reach others

- Having a say on their own support and development needs

- Creating their own job description.

As autonomous individuals, they are ready to leave if not fulfilled and supported, so collaboration and co-creation of their role, responsibilities and ways of working will be much more sustaining for a Cultural Creative than top down directives and low levels of autonomy.

\section{References}

Brown, M., Treviño, L. and Harrison, D. (2005). Ethical leadership: A social learning perspective for construct development and testing. Organizational Behavior and Human Decision Processes, 97(2), pp.117-134.

Darcy, K. T. (2010). Ethical leadership: The past, present and future. International Journal of Disclosure and Governance, 7(3), 198212.Gov.uk., 2012 Low Carbon Environmental Goods and Services (LCEGS) 
Report for 2011/12 Retrieved 28 January 2018, from

https://www.gov.uk/government/uploads/system/uploads/attachment_data /file/224068/bis-13-p143-low-carbon-and-environmental-goods-and-servicesreport-2011-12.pdf

Ray, P. \& Anderson, S. (2000). The Cultural Creatives: How 50 million people are changing the world (1 ${ }^{\text {st }}$ ed), New York: Harmony Books

Rittel, H. (1969). Reflections on the scientific and political significance of decision theory. Institute of Urban \& Regional Development, University of California

Vianello, M., \& Moore, G. (Eds.). (2004). Women and men in political and business elites: a comparative study in the industrialized world. Sage.

1417 words 